\title{
Myanmar's human rights crisis justifies foregoing neutrality for a solidarity-based approach to humanitarianism
}

Edition 7, 2021

Dr Anne Décobert

DOI: 10.37839/MAR2652-550X7.6

The February 2021 military coup has plunged Myanmar into chaos, rolling back progress achieved over the past decade in terms of human rights, development, and peacebuilding. Local populations are now facing a humanitarian catastrophe, with large-scale suffering caused by violence and displacement, an economic and food security crisis, and a public health emergency within which the junta has used COVID-19 to suppress the people.

Myanmar's multi-pronged crisis is not just a humanitarian one. This is a political and human rights crisis, within which international aid will inevitably have political impacts.

The decisions that international donors and aid organisations make in providing humanitarian assistance need to be guided by Myanmar's people, who have overwhelmingly rejected the military regime. In Myanmar's human rights crisis, pretences at neutrality would do more harm than good and a solidarity-based approach to aid will have far more positive humanitarian and human rights impacts. 


\section{A political and human rights crisis}

On February 1, 2021, the Myanmar military (Tatmadaw) seized power, deposing the country's democratically elected leaders. Myanmar citizens, political parties and most Ethnic Armed Organisations have rejected the military's actions and refused to recognise the military-run State Administration Council.

Over the past months, a Civil Disobedience Movement and popular protests have spread throughout the country. In historically disputed border areas, armed conflicts have reignited between the military and multiple Ethic Armed Organisations, driving further nails into the coffin of the 2015 Nationwide Ceasefire Agreement.

In response to the coup, elected Members of Parliament formed the Committee Representing Pyidaungsu Hluttaw. The Committee, along with pro-democracy parties, leaders of the Civil Disobedience Movement, civil society groups, and Ethnic Armed Organisations agreed to the 2021 Federal Democracy Charter, leading to the formation of the National Unity Government.

The National Unity Government is widely seen by Myanmar people and many Ethnic Organisations as a legitimate governing body, with many being hopeful that-if it succeeds in overriding the State Administration Council-it may finally realise longthwarted aspirations of ethnic groups for federal democracy, self-determination, and lasting peace. The National Unity Government has established a People's Defence Force, as a precursor to a Federal Union Army and to protect its supporters and other civilians from violence instigated by the military.

Amidst a political stalemate that could lead to full-blown civil war, civil disobedience and popular protests continue. And the military's brutal repression of these movements and increasing attacks on populations in areas controlled by Ethnic Armed Organisations are driving ever more suffering.

According to the United Nations Office for the Coordination of Humanitarian Affairs, 
three million people are in need of humanitarian aid, with numbers likely to keep rising. Close to a quarter of a million people have been displaced since the coup, due to military violence in urban centres and increasing conflict in ethnic states.

Myanmar is also heading towards deepening economic collapse and many areas are facing an impending food crisis. Poverty and insecurity are escalating throughout rural and urban populations, with incomes and livelihoods severely impacted.

All of this is compounded by a collapse in public health systems. Many of those who spearheaded the Civil Disobedience Movement were doctors, nurses and others in the government health system, who took a stand against renewed military rule. Health workers critical of the coup have been persecuted by the junta, with many arrested, abducted and/or killed, and many more forced into hiding.

Meanwhile, the country is facing a major public health crisis and a deadly new wave of COVID-19 is being weaponised by the junta, which is blaming medical professionals from the Civil Disobedience Movement for deaths, using COVID-19 restrictions to intensify repression of ethnic and democratic opposition groups, and denying medical assistance to people in need. Many hospitals are closed or occupied by the military, facilities are severely understaffed, and private clinics are unaffordable for most. Ongoing military attacks on health personnel and facilities further jeopardise the COVID-19 response, and constitute violations of medical neutrality and war crimes under international humanitarian law.

The people of Myanmar are in dire need of humanitarian aid. But this aid needs to be politically sensitive. And it is essential to 'frame' the current humanitarian crisis as a political and human rights crisis. Indeed, and as highlighted by Professor Hugo Slim in a talk hosted by Chiang Mai University, Myanmar is facing a political emergency in which a civil resistance movement is legitimately opposing a violent regime.

Of course, Myanmar has a long history of conflict between the Tatmadaw and Ethic Armed Organisations struggling for self-determination in border areas. But if international actors frame the whole of the situation in Myanmar as the result of 
conflict (or, worse, 'ethnic conflict'), it makes it far too easy for the State Administration Council to deny any responsibility. Opposition and ethnic nationality groups can then too easily be blamed for the situation-as indeed they are in the State Administration Council's labelling of the National Unity Government and other opposition groups as 'terrorist organisations'.

Instead, what is needed is recognition that, firstly-as analyst David Mathieson has highlighted-the humanitarian crisis cannot be isolated from what is a human rights crisis driven by a military bent on terrorising local populations to retain power; and, secondly, that deeply embedded structural violence and injustices lie at the root of Myanmar's decades-long conflicts. The post-coup human rights crisis has then aggravated long-standing conflict dynamics and deepened the historical vulnerabilities and insecurities of local populations-with all of this compounded by the COVID-19 pandemic.

'Framing' the crisis in Myanmar as a political and human rights crisis is obviously important from a moral perspective. It is also essential for the development of humanitarian programmes.

Indeed, any humanitarian intervention in a political crisis will inevitably have political impacts. And any intervention in a conflict situation 'will inevitably have an impact on the peace and conflict environment-positive or negative, direct or indirect, intentional or unintentional'. The decisions that international donors and aid organisations make in Myanmar today therefore carry heavy consequences.

\section{The politicisation of aid}

Myanmar's military has many times in the past restricted humanitarian access to conflict-affected populations and other civilians in need of aid-including during the initial response to Cyclone Nargis in 2008. It is highly likely that the new regime will create an increasingly difficult operational environment for international aid workers. 
The military has already blocked the delivery of humanitarian aid in many ethnic areas, as well as deliberately destroying food and medical supplies, diverting aid away from its intended recipients, and attacking aid workers. These acts constitute violations of international humanitarian law. And the more the military diverts and politicises aid, the more this will undermine humanitarian-as well as longer-team development and peacebuilding-aims, as it will bolster a regime that is the main driver of Myanmar's present crisis and of its historical impoverishment and insecurity.

There is also the risk that humanitarian aid will signal recognition by international actors of the State Administration Council. As highlighted by Thomas Weiss, decisions about how to channel assistance in situations of conflict and disputed governance inevitably entail 'judgements by outsiders about what is right and just, about whose capacities are built, about which local groups are favoured'.

There are good reasons why international organisations might want to maintain some engagement with the State Administration Council. It would enable them to preserve an official presence inside Myanmar, with this (hopefully) enabling access to populations in need of aid, as well as protection for their staff.

However, the regime is already preventing humanitarian organisations from accessing people in need. Staff of international organisations fear that the situation will only get worse, with some international Non-Government Organisations (NGOs) already required to sign new Memorandums of Understanding with the State Administration Council or to provide lists of staff. And there are major political and ethical implications in maintaining any kind of relationship that might signal international recognition of the State Administration Council.

For one-and even if this is not the intention of the agencies involved-international aid could legitimise a regime that is committing widespread and systematic attacks against the Myanmar people, which amount to crimes against humanity. Secondly, if international agencies are seen as 'siding' with the State Administration Council, 
this may sow distrust amongst local populations who overwhelmingly oppose the coup. Thirdly, this could create major tensions within aid agencies themselves-with many local staff opposing the State Administration Council.

Dilemmas around political recognition and legitimacy in turn link to ongoing debates about the principle of humanitarian neutrality. In the classic International Committee of the Red Cross definition, neutrality means 'not tak[ing] sides in hostilities or engag[ing] at any time in controversies of a political, racial, religious or ideological nature.'

Despite a long history of divisions over the viability of neutrality as a guiding principle for humanitarianism in complex political emergencies, many international donors and aid organisations still maintain that it is essential to humanitarian action. Yet as Hugo Slim highlights, 'neutral humanitarian action is one version of humanitarianism - not the only version' - and it is not necessary to be neutral to be a good humanitarian.

In Myanmar's political minefield, no matter how much they claim to be neutral, how international actors channel aid will not be perceived as a neutral act. Attempts at neutrality can also do real harm, particularly if-by not taking a stand or by having their aid politicised by the military regime-international actors end up emboldening and enabling those behind Myanmar's human rights crisis.

\section{Neutrality and evolving politics of aid}

The debate about humanitarian neutrality is far from new in Myanmar, with neutrality having been used in the past to justify shifts in international aid. These shifts were themselves influenced by political factors and had significant political consequences.

In the 1990s and 2000s, when Myanmar was under military rule, international donors provided aid in ways that essentially bypassed the junta-either by funding 
international NGOs or UN agencies operating inside Myanmar and/or by funding 'cross-border aid'. These approaches were shaped by isolationist policies and concerns that aid would be misappropriated by and bolster an illegitimate military regime.

'Cross-border aid' to Myanmar developed from the 1990s onwards, to channel assistance to remote and conflict-affected border areas where official health, education and other essential services were lacking and the state restricted international humanitarian access. Cross-border aid organisations build on deeply embedded service provision and governance systems in the ethnic states.

Cross-border systems include health, education and other service provision 'wings' of Ethnic Armed Organisations, along with community-based organisations that serve local communities in border areas under Ethnic Armed Organisation control. They channel international assistance into Myanmar from a management and logistics base in a neighbouring country (commonly, Thailand), but their staff come from and work within ethnic communities inside Myanmar.

In the 1990s and 2000s, funding for cross-border aid was provided by donors like Canada, Norway, Denmark, the US and UK. This funding was justified by the humanitarian needs of communities in border areas and by state restrictions on international humanitarian access. In the past, donors also described funding for cross-border aid as a way to support actors who were seen as legitimate 'agents of change' in Myanmar.

Ethnic and community-based service providers in border areas readily admit that they are not politically neutral-not only because they work with Ethnic Armed Organisations, which they see as legitimate governance systems, but also because many combine service provision with advocacy for the rights of ethnic communities and the establishment of federal democracy in Myanmar.

Members of these organisations also come from ethnic communities that were historically attacked and terrorised by Tatmadaw forces, as they are again now. As 
one leader told me, when I started working with cross-border groups over a decade ago, 'In this situation, you cannot be neutral. You cannot sit on the fence between good and bad.'

International funding for cross-border aid in the 1990s and 2000s amounted to what Weiss would call a 'solidarist' approach 'employing humanitarian action within a political strategy on behalf of victims'. But when donors' political aims in Myanmar shifted, so too did definitions of legitimate humanitarian action.

With conflict and displacement now increasing in the border areas, and with members of the Civil Disobedience Movement and other civilians from urban areas fleeing to areas controlled by Ethnic Armed Organisations, ethnic and communitybased service providers are facing increased demand for their services. Some of these organisations are also at the forefront of responding to COVID-19. And in providing lifesaving assistance to populations in need, some are also building on partnerships they developed over the past decade with actors in government health systems.

Ethnic and community-based service providers therefore have the human resources and networks in place to respond in Myanmar's current crisis. But they are in desperate need of funding. Supporting these organisations would obviously not be a neutral act.

But again, neutrality is not always necessary for good humanitarian action. Instead, as Slim highlights, 'the misguided orthodoxy that all humanitarian action must be neutral ... de-legitimises locally led aid when it is needed most.'

In the past, the principle of neutrality was used to discredit cross-border groups and justify a shifting politics of international aid. Changes to funding governmentapproved channels were in turn often seen as undermining local health and education systems and increasing centralised state control over border areas.

Yet the solidarist approach of ethnic and community-based organisations is a 
legitimate form of humanitarian action. And the human rights crisis in Myanmar today justifies a solidarity-based approach to the provision of international aid.

\section{Foregoing neutrality for solidarity}

Rather than trying to be neutral, what is important is that international donors and aid organisations do no harm. To achieve this, priority should be given to support that will not legitimise the State Administration Council.

At the same time, priority should be given to working with community-level and civil society actors in ways that enable the provision of life-saving humanitarian aid and that demonstrate real commitment to localisation. As Khin Ohmar argues, working around ethnic and community-based organisations rather than with them 'represents a continued colonisation of aid practices - a denial of locals' agency'.

In Myanmar, international actors have the opportunity to support organisations that have 'the expertise, local legitimacy, and vision to offer an alternative to traditional aid distribution practices.' Doing this will not only demonstrate genuine commitment to decolonising aid, but will help lay the foundations for longer-term equitable development and lasting peace in Myanmar.

To assist populations in conflict-affected border areas, international donors should fund cross-border aid, and international NGOs and UN bodies should work with ethnic and community-based service providers as equal partners, supporting the distribution of aid through these organisations. To address the current COVID-19 crisis, support should be coordinated with the COVID-19 Task Force, formed by the National Unity Government and Ethnic Health Organisations.

This is important to address immediate humanitarian needs, but also to contribute to longer-term development and peacebuilding aims. Myanmar's military coup and defunct peace process highlight what many analysts had said all along: that equitable development and lasting peace will never be achieved without real, 
systemic change-without reducing the control of the Bamar military elite over the state and without recognising and strengthening ethnic service and governance systems. Supporting and building the sustainability of ethnic and community-based service systems will help to address some of the structural inequities and injustices that have fed into decades of conflict in Myanmar.

At the same time, populations in more central, government-controlled areas are also in dire need of humanitarian aid. To access these populations, international NGOs and UN agencies should listen to civil society and community-level actors, and work with these actors in ways that limit involvement from the State Administration Council and that enable true localisation of humanitarian decision-making and responses.

Moreover, with Myanmar's current COVID-19 crisis presenting severe risks for the wider region, there is a clear impetus and need for a regional response. Diplomatic and political pressure must be exerted by international donor countries on Myanmar's neighbours, to allow for unrestricted cross-border humanitarian operations. At the same time, pressure must also be exerted on the Association of Southeast Asian Nations and neighbouring countries, to help negotiate access for the COVID-19 response and advocate for the protection of health workers across the country.

Ultimately, international approaches must be informed by Myanmar civil society and the National Unity Government's risk assessments and suggested ways of operating. The establishment of humanitarian partnerships with these actors will in turn signal that international donors and aid organisations do not endorse the State Administration Council as Myanmar's legitimate governing body.

With Myanmar's human rights crisis forcing international actors to recognise that aid is politicised and has political impacts, international donors and aid organisations must remain committed to provided life-saving humanitarian aid. But in doing so, they must also demonstrate solidarity with the people of Myanmar, who 
have overwhelmingly rejected the military regime and continue to suffer because of its violent actions.

Image: Community health worker providing COVID-19 education to villagers in Myanmar. Credit: Back Pack Health Worker Team. 